\title{
RENT EXTRACTION PADA PERUSAHAAN DENGAN STRUKTUR KEPEMILIKAN TERKONSENTRASI DI BURSA EFEK INDONESIA
}

\author{
Ni Ketut Surasni ${ }^{1}$, Hermanto ${ }^{2}$, Hermanto ${ }^{3}$ \\ 1Fakultas Ekonomi dan Bisnis Unram. E-mail: surasni12@gmail.com \\ 2Fakultas Ekonomi dan Bisnis Unram. E-mail: hermanto57@gmail.com \\ 3Fakultas Ekonomi dan Bisnis Unram. E-mail: hermanto2307@gmail.com
}

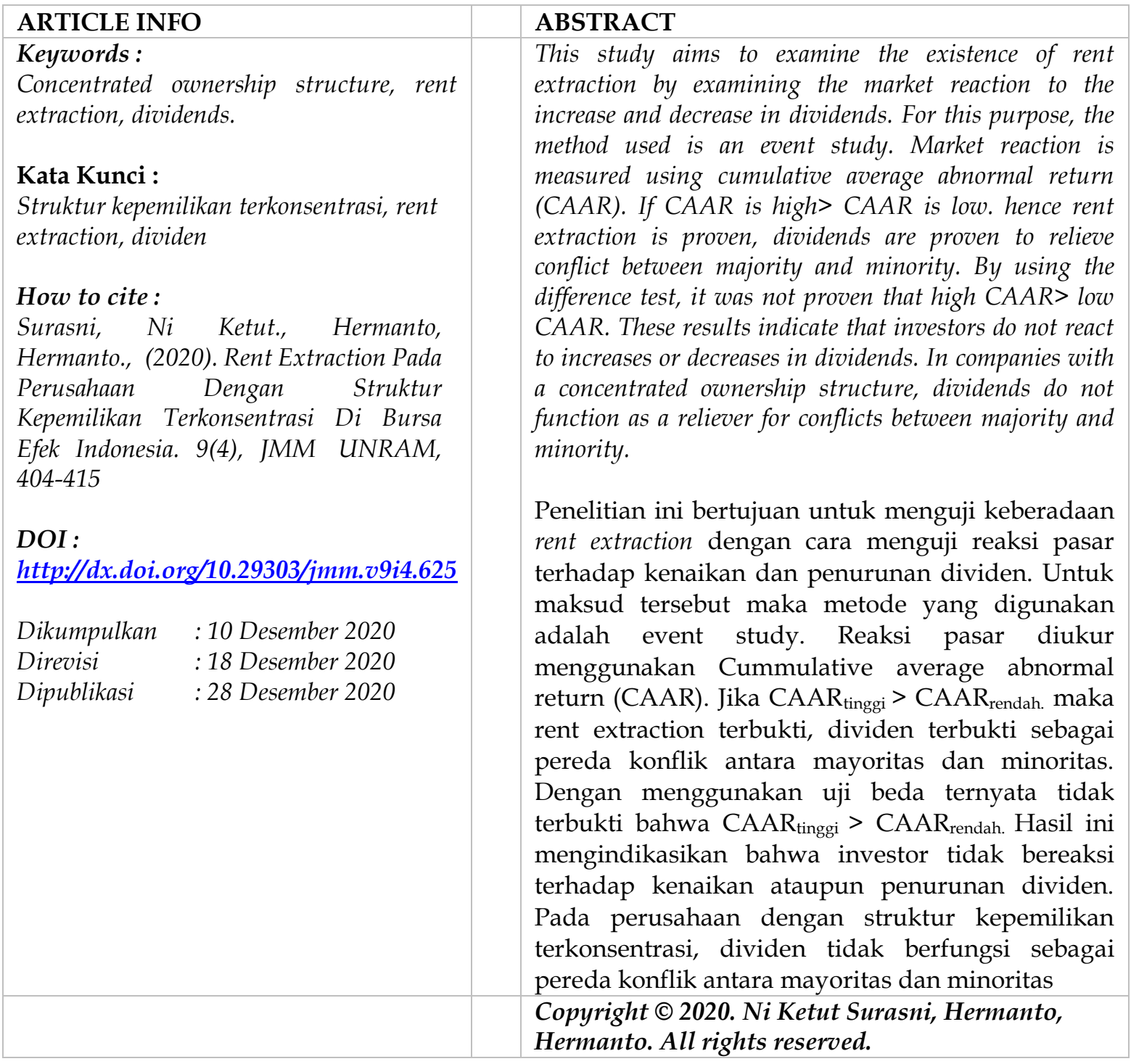




\section{PENDAHULUAN}

Teori keagenan merupakan suatu teori yang diajukan oleh Jensen dan Meckling (1976). Mereka menyatakan bahwa ketika pengelolaan perusahaan bukan dilakukan oleh pemilik maka akan memunculkan potensi konflik antara pemilik dan pengelola. Hal ini bersumber pada informasi yang tidak simetris dan perbedaan self interest antar pihak-pihak yang terlibat di dalam suatu perusahaan (organisasi). Pemilik (principal), memberikan kewenangan kepada manajer (agent) untuk mengelola asset perusahaan demi kepentingan pemilik. Akan tetapi dikarenakan pemilik dan pengelola merupakan orang yang berbeda maka, mereka cenderung memiliki kepentingan (self interst) yang berbeda pula. Manajer cenderung melakukan kegiatan/kebijakan berdasarkan kepentingan mereka sendiri. Perilaku manajer ini memunculkan konflik antara manajer dan pemegang saham.

Pada awal perkembangannya, teori keagenan membahas konflik keagenan antara pemilik (pemegang saham) dengan manajer atau antara pemegang saham dengan kreditur (Jensen dan Meckling, 1976). Namun dalam perkembangan selanjutnya, konflik keagenan meluas, terjadi antara pemegang saham mayoritas dengan minoritas (LaPorta, Lopez-deSilanes, Shleifer,2000), antara pemegang saham mayoritas dengan stake holder lainnya seperti pemasok dan karyawan (Zhuang et al, 2000).

Menurut Shleifer dan Vishny (1986), salah satu cara untuk meredakan konflik antara manajer dengan pemegang saham adalah adanya kepemilikan-blok (blockholder ownership) atau sering juga disebut kepemilikan terkonsentrasi karena kepemilikan saham hanya terkonsentrasi pada beberapa pemilik saja. Blockholder dimaksudkan sebagai pengontrol manajer agar tidak melakukan perilaku merugikan pemegang saham. Hal ini dimungkinkan karena blokholder akan memiliki hak suara yang lebih besar yang mampu mengendalikan manajer. Namun demikian, ada sisi negatif struktur kepemilikan terkonsentrasi ini yaitu memunculkan konflik baru antara pemegang saham mayoritas dan minoritas. Konflik-baru muncul karena blokholder dan manajer memiliki kecenderungan kerja-sama untuk merugikan pemegang saham minoritas. Inilah yang disebut rent extraction hypothesis (Gugler dan Yurtoglu,2000)

Struktur kepemilikan perusahaan-perusahaan yang tercatat di Bursa Efek Indonesia sebagian besar merupakan struktur kepemilikan mayoritas (Gunarsih, 2003; Mutamimah, 2006). Oleh karena itu maka struktur kepemilikannya merupakan struktur terkonsentrasi, karena pemilik-mayoritas dapat mengontrol aktivitas perusahaan. Struktur kepemilikan terkonsentrasi ini merupakan area yang sangat tepat untuk melakukan pengujian konflik keagenan antara mayoritas dan minoritas melalui mekanisme kebijakan dividen.

Kebijakan dividen merupakan suatu mekanisme untuk mengurangi konflik keagenan di dalam perusahaan (Gugler dan Yurtoglu,2000; Lang dan Litzerberger, 1988). Peningkatan dividen dapat menurunkan Free Cash Flow perusahaan, sehingga dengan demikian hal ini dapat menunjukkan bahwa pemilik-mayoritas tidak menggunakan kas perusahaan untuk kepentingannya sendiri melainkan membagikannya sebagai dividen. Pembayaran dividen menunjukkan bahwa hak-hak pemilik-minoritas terpenuhi. Sebaliknya penurunan dividen mengindikasikan pemilik-mayoritas menggunakan kas untuk kepentingan mereka dan merugikan pemilik-minoritas. Kebijakan dividen dikatakan efektif sebagai mengurang konflik keagenan jika kenaikan dividen direaksi positif oleh pasar. Oleh karena itu maka kebijakan kenaikan (penurunan) dividen akan direaksi positif (negative) oleh pasar. 
Gugler dan Yurtoglu (2000), meneliti peran dividen sebagai pereda konflik antara pemilik-mayoritas dan pemilik-minoritas.Mereka menemukan bahwa terdapat return taknormal positif pada kenaikan dividend dan return taknormal negatif pada penurunan dividen. Pembayaran dividen dapat menjadi sinyal ketidak-inginan pemilik mayoritas mengeksploitasi kas demi kepentingannya sendiri. Sebaliknya penurunan dividen menunjukkan rent extraction pemilik-minoritas oleh pemilik-mayoritas. Dewenter dan Warter (1998) menunjukkan bahwa pasar bereaksi lebih besar pada perusahaan yang memiliki konflik keagenan lebih besar daripada yang memiliki konflik keagenan lebih kecil.

Penelitian ini difokuskan pada keberadaan rent extraction oleh mayoritas kepada minoritas. Penelitian ini menggunakan dividen sebagai pendeteksi keberadaan rent extraction. Ketika dividen ditingkatkan maka ini merupakan indikasi mayoritas tidak melakukan rent extraction karena hak minoritas atas dividen sudah terpenuhi. Ketika dividen diturunkan maka ini merupakan indikasi mayoritas melakukan rent extraction terhadap minoritas karena mengurangi hak minoritas. Dengan demikian maka reaksi pasar akan positif ketika dividen naik dan akan bereaksi negative ketika dividen turun.

\section{KAJIAN TEORI DAN RISET TERDAHULU}

\subsection{Perkembangan Teori Keagenan}

Menurut Jensen dan Meckling (1976), pemisahan antara pemilik dan pengelola akan menimbulkan konflik. Hubungan kerja antara manajer (pengelola) dengan pemilik diatur dalam suatu kontrak. Dalam kontrak tersebut diatur bahwa pemilik mendelegasikan kewenangan pengelolaan perusahaan kepada manajer. Manajer mengelola perusahaan atas kepentingan pemilik agar pemilik menjadi lebih makmur. Sebagai imbalannya manajer akan memperoleh gaji, bonus, kompensasi dan insentif lainnya atas pekerjaan mereka.

Secara ideal, agen (manajer) merupakan orang yang dapat dipercaya untuk melaksanakan tanggung jawab memaksimumkan kemakmuran pemegang saham. Walaupun sudah ada kontrak, namun karena yang menguasai asset perusahaan adalah manajer maka seringkali manajer melakukan keputusan-keputusan berdasarkan pertimbangan kepentingannya sendiri. Dalam konteks teori keagenan maka perilaku manajer yang merugikan pemilik tersebut dinamakan rent extraction.

Di dalam perkembangannya, masalah keagenan menjadi lebih kompleks, bukan hanya konflik antara manajer dan pemegang saham tetapi antara pemegang saham mayoritas dan minoritas. Munculnya masalah keagenan antara mayoritas dan minoritas ini disebabkan beberapa hal. Pertama, pemegang saham mayoritas seringkali merupakan manajer atau dewan direksi maupun dewan komisaris, mereka terlibat didalam manajemen perusahaan dan memiliki kesempatan besar untuk melakukan rent extraction terhadap pemegang saham minoritas (Mitton, 2002). Kedua, hak suara yang dimiliki pemegang saham mayoritas melebihi hak atas arus kasnya karena adanya kepemilikan saham bentuk bersilang, piramida (Claessens, Djankov dan Lang, 2000). Dengan bentuk kepemilikan seperti ini mendorong pemegang saham mayoritas untuk mengutamankan kepentingan mereka sendiri. Ketiga, pemegang saham mayoritas mempunyai kekuatan untuk mempengaruhi manajemen dalam membuat keputusan-keputusan yang hanya mementingkan diri sendiri. Keempat, adanya perlindungan hak-hak pemegang saham minoritas yang lemah, mendorong pemegang saham mayoritas melakukan rent extraction terhadap pemegang saham minoritas (Claessens dan Fan, 2002).

\subsection{Dividen Sebagai Pereda/Pengurang Konflik Keagenan}


Salah satu cara yang dapat ditempuh untuk menurunkan konflik adalah kebijakan dividen. Dividen menurunkan konflik yang terjadi antara pemilik-mayoritas dan pemilikminoritas. Kenaikan dividen dapat mengurangi arus kas bebas (free cash flow) dan untuk menunjukkan kepada publik bahwa pemegang saham mayoritas tidak menggunakan arus kas untuk kepentingannya sendiri. Pemegang saham mayoritas tidak mengabaikan kepentingan pemegang saham minoritas, dividen dibagikan kepada seluruh pemegang saham (Gugler dan Yurtoglu, 2000).

\subsection{Penelitian Terdahulu}

Struktur kepemilikan terkonsentrasi menimbulkan konflik keagenan antara pemegang saham mayoritas dengan minoritas (Shleifer dan Vishny, 1997; Zhuang at al., 2000). Pemegang saham mayoritas mempunyai kekuatan yang lebih besar untuk mengendalikan manajer dalam pengambilan keputusan, misalnya terkait dengan aliran kas bebas dalam perusahaan. Dalam hal ini kebijakan dividen dapat digunakan sebagai mekanisme untuk mengurangi konflik keagenan antara pemegang saham mayoritas dengan minoritas. Hal ini karena kenaikan dividen dapat menunjukkan kepada publik bahwa pemegang saham mayoritas tidak menggunakan arus kas bebas untuk kepentingan mereka saja, namun dibagikan kepada pemegang saham (Gugler dan Yurtoglu, 2000).

Struktur kepemilikan menentukan jenis konflik keagenan di dalam suatu perusahaan publik. Pada perusahaan dengan struktur kepemilikan terkonsentrasi, maka konflik yang utama adalah antara pemegang saham mayoritas dan minoritas (Shleifer dan Vishny, 1997);Zhuang et al, 2000). Shleifer dan Vishny (1997) menyatakan bahwa pemegang saham mayoritas akan mampu mengendalikan perusahaan secara penuh sehingga mereka cenderung membuat kebijakan perusahaan yang hanya bermanfaat untuk mereka sendiri. Semakin tinggi konsentrasi kepemilikan suatu perusahaan maka konflik keagenan antara mayoritas dan minoritas akan semakin tinggi (Gugler dan Yurtoglu,2000; Dewenter dan Warther, 1998).

\section{METODE PENELITIAN}

\subsection{Populasi dan Sampel}

Populasi dalam penelitian ini adalah seluruh perusahaan yang terdaftar di pasar modal Indonesia. Pemilihan sampel berdasarkan purposive sampling dengan kriteria sebagai berikut:

1. Perusahaan yang sahamnya dimiliki oleh pemegang saham dengan kepemilikan saham minimal 5\% (jumlah ini mengacu pada Shleifer Vishny 2000).

2. Perusahaan mengumumkan pembagian dividen

Selanjutnya sampel akan dibagi menjadi dua yaitu struktur kepemilikan terkonsentrasi tinggi dan rendah. Adapun cara pembagiannya adalah, jika kepemilikan $\geq$ rata-rata maka termasuk kedalam jenis perusahaan terkonsentrasi tinggi. Jika kepemilikan < rata-rata maka termasuk kedalam jenis perusahaan terkonsentrasi rendah.

\subsection{Data dan Sumber Data}

Jenis data yang digunakan dalam penelitian ini adalah data sekunder, yaitu laporan keuangan perusahaan, tanggal pengumuman dividen, harga saham harian, indeks harga saham gabungan harian, kepemilikan saham, price to book value dan informasi-informasi lainnya yang terkait dengan penelitian ini. Tanggal pengumuman dividen adalah saat kebijakan tersebut diumumkan ke publik melalui media masa. Adapun data yang digunakan diperoleh melalui www.idx.com. 


\subsection{Variabel dan Pengukurannya}

Penelitian ini menggunakan model studi peristiwa ( event study ). Reaksi pasar akan diukur menggunakan average abnormal return (Husnan, 2001; Gugler dan Yurtoglu,2000) serta cumulative average abnormal return (Gugler dan Yurtoglu,2000). AAR (average abnormal return) yang diamati adalah return saat pengumuman/event $(\mathrm{t}=0)$. Sedangkan CAAR (cumulative average abnormal return) yang akan diuji adalah satu hari sebelum pengumuman sampai dengan satu hari setelah pengumuman; dua hari sebelum pengumuman sampai dengan dua hari setelah pengumuman dan seterusnya hingga lima hari sebelum pengumuan sampai dengan lima hari setelah pengumuman.

Untuk menjawab permasalahan penelitian yang diuji dengan indikator pasar, maka akan digunakan analisis dengan metode studi peristiwa. Terlebih dahulu ditentukan nilai AAR dan CAAR. Event dalam penelitian ini adalah pengumuman pembagian dividen. Abnormal return (AR) atau return taknormal adalah selisih actual return dengan expected return. Sedangkan CAAR merupakan jumlah AR selama jumlah periode window tertentu (dalam hal ini sampai dengan 5 hari). Adapun langkah-langkah pengujiannya sebagai berikut:

1. Menentukan expected return dengan menggunakan model market adjusted return. Model ini mengasumsikan bahwa return saham sama dengan return pasar yang diperoleh dari return indeks harga saham gabungan (IHSG).

2. Menentukan event window. Dalam penelitian ini menggunakan window 5 hari sebelum pengumuman sampai dengan lima hari sesudah pengumuman.

3. Menghitung return pasar dengan rumus:

$$
\mathbf{R}_{\mathrm{mt}} \quad=\left(\mathrm{HISG}_{\mathrm{t}}-\mathrm{IHSG}_{\mathrm{t}-1}\right) /\left(\mathrm{IHSG}_{\mathrm{t}-1}\right)
$$

4. Menghitung return aktual untuk saham dengan rumus:

$$
\mathbf{R}_{\text {it }} \quad=\left(\mathbf{P}_{\mathbf{t}}-\mathbf{P}_{\mathrm{t}-1}\right) /\left(\mathbf{P}_{\mathrm{t}}\right)
$$

5. Menghitung return taknornal dengan rumus:

$$
\text { AR }=\mathbf{R}_{\text {it }}-\mathbf{R}_{\mathrm{mt}}
$$

6. Menghitung cumulative average abnormal return dengan rumus:

$$
\mathrm{CAAR}=\sum_{\mathrm{t}}^{k} \mathrm{AAR}
$$

Keterangan;

IHSG : Indeks Harga Saham Gabungan

$\mathrm{P} \quad$ : Harga saham

\section{ANALISIS}

Bagian ini menyajikan dan membahas hasil pengujian empiris reaksi pasar terhadap pengumuman dividen. Jika pasar bereaksi positif (negative) terhadap pengumuman kenaikan (penurunan) dividen maka hal ini menunjukkan dividen mampu mengurangi konflik (hipotesis rent extraction terbukti). Selanjutnya dilakukan pengujian perbedaan reaksi pasar terhadap pengumuman dividen pada perusahaan terkonsentrasi tinggi dan terkonsentrasi rendah. Harapannya adalah reaksi pasar pada perusahaan terkonsentrasi tinggi akan lebih tinggi dibandingkan dengan pada perusahaan terkonsentrasi rendah. Reaksi pasar diukur menggunakan AAR dan CAAR disekitar pengumuman dividen baik untuk dividen naik maupun dividen turun.

\subsection{Average Abnormal Return di Sekitar Pengumuman Kenaikan Dividen}

Pertama-tama pengujian reaksi pasar akan menggunakan data AAR (average abnormal return) untuk perusahaan-perusahaan dengan dividen naik. Hasil uji dapat dilihat pada tabel 4.1 berikut ini. 
Tabel 4.1

AAR Perusahaan Dengan Dividen Naik

\begin{tabular}{|c|c|c|c|}
\hline Hari ke & AAR & t statistik & signifikansi \\
\hline-5 & $-0,00151$ & $-0,014$ & Tidak \\
\hline-4 & 0,00167 & 0,248 & Tidak \\
\hline-3 & 0,00009 & 0,364 & Tidak \\
\hline-2 & 0,00641 & 2,117 & Signifikan \\
\hline-1 & 0,00059 & 0,033 & tidak \\
\hline 0 & 0,00333 & 0,645 & Tidak \\
\hline 1 & $-0,02854$ & $-4,739$ & Signifikan \\
\hline 2 & $-0,00923$ & $-1,485$ & Tidak \\
\hline 3 & $-0,00536$ & $-1,733$ & Tidak \\
\hline 4 & $-0,0004$ & $-0,137$ & Tidak \\
\hline 5 & 0,00274 & 1,076 & tidak \\
\hline
\end{tabular}

Dari tabel 4.1 nampak bahwa hampir seluruh hari disekitar pengumuman dividen naik tidak menunjukkan reaksi pasar karena sebagian besar tidak signifikan. AR yang signifikan hanya di hari ke 2 sebelum pengumuman dividen dan dihari pertama setelah pengumuman dividen. Walaupun hari tersebut menunjukkan terdapat abnormal return akan tetapi dengan tanda yang negative. Ini tidak sesuai dengan harapan bahwa semestinya pengumuman kenaikan dividen direaksi positif oleh investor. Sebaliknya hasil penelitian ini menunjukkan reaksi yang negative. Penggunaan AAR didalam mengukur reaksi pasar tidak mendapatkan hasil seperti yang diharapkan.

\subsection{Cummulative Average Abnormal Return di Sekitar Pengumuman Kenaikan Dividen}

Cara lain untuk melakukan pengujian reaksi pasar adalah menggunakan CAAR. Data rata-rata CAAR (cumulative average abnormal return) untuk perusahaan-perusahaan yang menaikkan dividen dapat dilihat pada tabel 4.2 berikut ini

Tabel 4.2

CAAR Perusahaan Dengan Dividen Naik

\begin{tabular}{|l|c|c|c|}
\hline & Nilai & t statistik & Signifikansi \\
\hline CAR1 & $-0,02461$ & $-3,921$ & Signifikan \\
\hline CAR2 & $-0,02743$ & $-2,533$ & Signifikan \\
\hline CAR3 & $-0,03270$ & $-2,702$ & Signifikan \\
\hline CAR4 & $-0,03143$ & $-2,395$ & Signifikan \\
\hline CAR5 & $-0,0302$ & $-1,492$ & tidak \\
\hline
\end{tabular}

Tabel 4.2, menunjukkan bahwa hanya CAAR5 yang tidak signifikan, sedangkan yang lain signifikan. Namun demikian seluruh CAAR bertanda negative. Dengan demikian maka investor tidak memperoleh return yang positif tetapi justru memperoleh return yang negative. Pengujian ini tidak dapat membuktikan keberadaan rent extraction. Dengan kata lain teori keagenan mayoritas dan minoritas tidak terbukti.

Hasil yang dapat disimpulkan dari table 4.2 adalah justru investor bereaksi negative terhadap kenaikan dividen. Temuan penelitian ini tidak mendukung temuan Gugler dan Yortoglu (2000) maupun temuan Mutamimah (2006). Temuan penelitian ini justru mendukung teori dividen tax preference. Teori ini menyatakan bahwa investor lebih menyukai capital gain dibandingkan dengan dividen. Jika dividen naik maka investor akan bereaksi negative karena pengenaan pajak yang tinggi kepada dividen. Dengan kata lain investor lebih menyukai dividen yang rendah. 


\subsection{Average Abnormal Return di Sekitar Pengumuman Penurunan Dividen}

Selanjutnya akan diuji reaksi pasar terhadap penurunan dividen. Pertama-tama reaksi pasar diukur menggunakan AAR. Data AAR (average abnormal return) untuk perusahaan-perusahaan dengan dividen turun dapat dilihat pada tabel 4.3 berikut ini.

Tabel 4.3

AAR Perusahaan Dengan Dividen Turun

\begin{tabular}{|c|c|c|c|}
\hline Hari ke & AAR & t statistik & signifikansi \\
\hline-5 & $-0,00087$ & $-0,200$ & Tidak \\
\hline-4 & 0,00508 & 0,771 & Tidak \\
\hline-3 & 0,01348 & 2,505 & Signifikan \\
\hline-2 & 0,00079 & 0,262 & Tidak \\
\hline-1 & 0,00395 & 0,909 & Tidak \\
\hline 0 & 0,00281 & 0,560 & Tidak \\
\hline 1 & $-0,01819$ & $-0,647$ & Tidak \\
\hline 2 & $-0,00696$ & $-1,932$ & Tidak \\
\hline 3 & $-0,00460$ & $-0,893$ & Tidak \\
\hline 4 & 0,00031 & 0,051 & Tidak \\
\hline 5 & 0,00331 & 0,463 & tidak \\
\hline
\end{tabular}

Sebagaimana halnya table 4.1. maka tabel 4.3, juga menunjukkan bahwa hampir di semua hari tak ada reaksi terhadap penurunan dividen. Hanya di hari ke -3 investor memperoleh abnormal return yang positif. Selanjutnya reaksi pasar akan diukur menggunakan CAAR.

\subsection{Cummulative Average Abnormal Return di Sekitar Pengumuman Penurunan Dividen}

Data CAAR (cumulative abnormal return) untuk perusahaan-perusahaan yang menurunkan dividen dapat dilihat pada tabel 4.4 berikut ini

Tabel 4.4

CAAR Perusahaan Dengan Dividen Turun

\begin{tabular}{|l|c|c|c|}
\hline & Nilai & $\mathrm{t}$ statistik & Signifikansi \\
\hline CAAR1 & $-0,01142$ & $-1,585$ & tidak \\
\hline CAAR2 & $-0,01760$ & $-1,713$ & tidak \\
\hline CAAR3 & $-0,00871$ & $-0,738$ & tidak \\
\hline CAAR4 & $-0,00332$ & $-0,272$ & tidak \\
\hline CAAR5 & $-0,00917$ & $-0,062$ & tidak \\
\hline
\end{tabular}

Dari tabel 4.4, dapat dilihat bahwa seluruh CAAR tidak ada yang signifikan. Walaupun tidak ada yang signifikan namun demikian seluruh CAAR bertanda negative sebagaimana yang diharapkan bahwa investor akan bereaksi negative ketika perusahaan menurunkan dividen. Dengan demikian dapat dikatakan bahwa investor cenderung bereaksi negative terhadap pengumuman penurunan dividen. Walaupun ada kecenderungan investor bereaksi negative terhadap penurunan dividen, namun karena reaksi tersebut tidak signifikan maka bisa juga disimpulkan bahwa investor bereaksi cepat terhadap penurunan dividen. Temuan ini juga memiliki kecenderungan pasar efisien, artinya informasi terserap dengan sangat cepat sehingga investor tidak memperoleh abnormal return. Rata-rata penurunan dividen pada sampel perusahaan sekitar $0,4 \%$. Nilai ini tidak cukup besar bagi investor untuk bereaksi terhadap penurunan dividen, sehingga hasilnya menjadi tidak signifikan. 
4.5. Cummulative Average Abnormal Return Perusahaan Terkonsentrasi Tinggi dan Rendah Yang Mengumumkan Kenaikan Dividen

Selanjutnya perusahaan-perusahaan yang mengumumkan kenaikan dividen akan dibagi menjadi dua kelompok, yang kepemilikannya terkonsentrasi tinggi dan rendah. Seluruh perusahaan yang mengumumkan kenaikan dividen merupakan perusahaan dengan struktur kepemilikan terkonsentrasi. Pembagian kelompok berdasarkan rata-rata kepemilikan terkonsentrasi. Jika kepemilikannya lebih besar dari rata-rata maka termasuk terkonsentrasi tinggi dan sebaliknya yang lebih rendah dari rata-rata termasuk terkonsentrasi rendah. Masing-masing kelompok tersebut diuji perbedaan CAR nya. Hasil uji beda dapat dilihat pada tabel 4.5 berikut ini

Tabel 4.5

Uji Beda CAAR Perusahaan Terkonsentrasi Tinggi Dan Rendah Yang Mengumumkan Kenaikan Dividen

\begin{tabular}{|c|c|c|c|c|}
\hline & $\begin{array}{c}\text { Terkonsentrasi } \\
\text { tinggi }\end{array}$ & $\begin{array}{c}\text { Terkonsentrasi } \\
\text { rendah }\end{array}$ & t statistik & signifikansi \\
\hline CAAR1 & $-0,0303$ & $-0,0168$ & $-1,504$ & tidak \\
\hline CAAR2 & $-0,0263$ & $-0,0289$ & 0,115 & tidak \\
\hline CAAR3 & $-0,0290$ & $-0,0377$ & 0,372 & tidak \\
\hline CAAR4 & $-0,0253$ & $-0,0398$ & 0,632 & tidak \\
\hline CAAR5 & $-0,0187$ & $-0,0460$ & 0,864 & tidak \\
\hline
\end{tabular}

Tabel 4.5 menunjukkan bahwa seluruh CAAR tidak berbeda antara perusahaan terkonsentrasi tinggi dan rendah. Investor tidak bereaksi berbeda terhadap kenaikan dividen pada perusahaan terkonsentrasi tinggi dan rendah. Dengan demikian maka dividen tidak berperan di dalam menurunkan konflik antara pemilik mayoritas dan minoritas pada peusahaan yang menaikkan dividen.

\subsection{Cummulative Average Abnormal Return Perusahaan Terkonsentrasi Tinggi dan} Rendah Yang Mengumumkan Penurunan Dividen

Sebagaimana pada perusahaan yang menaikkan dividen, maka perusahaan yang menurunkan dividenpun diuji perbedaan CAAR antara perusahaan terkonsentrasi tinggi dan rendah. Perhitungannya dapat dilihat pada tabel 4.6 berikut ini

\section{Tabel 4.6}

\section{Uji Beda CAAR Perusahaan Terkonsentrasi Tinggi Dan Rendah Yang Mengumumkan} Penurunan Dividen

\begin{tabular}{|c|c|c|c|c|}
\hline & $\begin{array}{c}\text { Terkonsentrasi } \\
\text { tinggi }\end{array}$ & $\begin{array}{c}\text { Terkonsentrasi } \\
\text { rendah }\end{array}$ & $\mathrm{t}$ statistik & signifikansi \\
\hline CAAR1 & $-0,0078$ & $-0,0191$ & 0,819 & tidak \\
\hline CAAR2 & $-0,0137$ & $-0,0259$ & 0,581 & tidak \\
\hline CAAR3 & $-0,0087$ & $-0,0088$ & 0,007 & tidak \\
\hline CAAR4 & $-0,0051$ & 0,0004 & $-0,210$ & tidak \\
\hline CAAR5 & $-0,0005$ & $-0,0018$ & 0,044 & tidak \\
\hline
\end{tabular}

Tabel 4.6 menunjukkan bahwa CAAR perusahaan yang menurunkan dividen tidak berbeda antara perusahaan yang terkonsentrasi tinggi dan rendah. Dengan kata lain bahwa reaksi investor pada perusahaan terkonsentrasi tinggi tidak lebih tinggi daripada yang terkonsentrasi rendah. Dividen tidak berperan dalam menurunkan konflik antara mayoritas dengan minoritas. 


\section{KESIMPULAN DAN SARAN}

\subsection{Kesimpulan}

1. Reaksi investor (pasar) terhadap kenaikan dividen adalah negative. Hal ini mengindikasikan investor tidak menyukai dividen yang tinggi. Teori yang sesuai dengan hasil empiris ini adalah teori tax preference, investor bereaksi negative jika dividen dinaikkan.

2. Reaksi investor terhadap penurunan dividen adalah negative tidak signifikan. Hal ini mengindikasikan ada kecenderungan investor bereaksi negative terhadap penurunan dividen.

3. Dividen tidak terbukti sebagai pereda konflik antara pemegang saham mayoritas dengan minoritas. Tidak terbukti ada rent extraction pada penelitian ini.

\subsection{Saran}

Tidak terbuktinya dividen sebagai pereda konflik membuat ada celah yang memungkinkan untuk pengujian lebih lanjut. Ada kemungkinan bahwa dividen tidak berdiri sendiri namun ada suatu kondisi yang ikut berpengaruh pada hubungan dividen dengan reaksi investor atau pasar. Salah satu yang bisa dipertimbangkan adalah kesempatan investasi. Signal dividen tentu saja akan dipengaruhi oleh kesempatan investasi dari perusahaan. Jika kesempatan investasinya tinggi, maka akan berpengaruh pada persepsi investor terhadap dividen yang naik maupun yang turun. Memasukkan variabel kondisional akan mengubah hubungan menjadi lebih kompleks namun lebih mendekati kenyataan. 


\section{DAFTAR PUSTAKA}

Claessens, Stijn, Djankov, Simeon, and Lang, Larry H.P. (2000),"The Separation of Ownership and Conrol in East Asian Corporations, Journal of Financial Economics, pp. 81-112.

(2001), "Disentangling the Incentive and Entrenchment Effect of Large Shareholdings", Journal of Finance, pp. 1-44.

Dewenter, Kathyn L, and Warther, Vincenta A. (1998)," Dividens, asymetric Information, and Agency Conflicts : Evidence from a Comparison of the Dividend Policies of Japanese and U.S. Firms, The Journal of Finance, June, pp.879- 904.

Easterbrook, F. (1984),"Two Agency Cost Explanation of Dividens", American Economic Review, September, pp. 650-659.

Eisenhardt, Kathleen M. (1989),"Agency Theory : An Assessment and Review", Academy of Management Review, pp.57-74.

Gugler and Yurtoglu (2000),"Corporate Governance and Dividend Pay-Out Policy in Germany", Europian Economic Review.

Gujarati, Damodar (2003),"Basic Econometrics", Fourth Edition, McGraw-Hill.

Gunarsih, Tri (2003), "Pengaruh Struktur Kepemilikan Dalam Corporate Governance dan Strategi Diversifikasi Terhadap Kinerja Perusahaan, Disertasi Fakultas Ekonomika dan Bisnis Universitas Gadjah Mada, Tidak Dipublikasikan.

Husnan, Suad (2001),"Corporate Governance dan Keputusan Pendanaan: Perbandingan Kinerja Perusahaan dengan Pemegang saham pengendali Perusahaan Multinasional dan bukan Multinasional", Journal of Accounting, Management, Economics Research, vol. 1 no. 1, Februari, pp. 1-12.

Jensen, M. (1986),"Agency Cost of Free Cash Flow, Corporate Finance, and Takeovers", American Economics Review, vol. 76, 1986, pp. 323-326.

Jensen M. and W.H. Meckling (1976),"'Theory of the Firm : Managerial Behavior, Agency Cost and Ownership Structure", Journal of Financial Economics, 3, 1976, pp. 305-360.

Kallapur, Sanjai and Mark A. Trombley (1999),"The Association between Investment Opportunity Set Proxies and Realized Growth", Journal of Business Finance and Accounting, pp. 505-519.

Lang, Larry H.P., Stulz, Rene M. and Walking, Ralph A.(1991)," A test of the Free Cash Flow Hyphothesis", Journal of Financial Economics, pp. 315-335.

LaPorta, Rafael, Florencio Lopez-de-Silanes, Andrei Shleifer, and Robert W. Vishny (1998)," Law and Finance", Journal of Political Economy, Desember, pp. 1113-1155.

Corporate Governance", Journal of Financial Economics, pp.3-27.

(2000),'Agency Problems and

Dividend Policies around the World", The Journal of Finance, Februari, pp. 1-33.

Morck, R., Shleifer A., and Vishny R.W. (1990),"do Managerial Objectives Drive Bad Acquisitions", The Journal of Finance, Vol. XLV, no. 1

Murali R., and J.B. Welch (1989),"Agents, Owners, Control, and Performance", Journal of Business Finance and Accounting, 16, 1989, pp.385-398.

Mutamimah (2006), Kebijakan Dividen, Utang dan Investasi Sebagai Mekanisme Pengurang Konflik Keagenan Antara Pemegang Saham Mayoritas dengan Minoritas, Fakultas Ekonomika dan Bisnis Universitas Gadjah Mada, Disertasi Tidak Dipublikasikan

Shleifer, A. and Robert W. Vishny, 1986, Large Shareholders and Corporate Control, The Journal of Political Economy, Vol. 94. 
Shleifer, A. and Robert W. Vishny,1989, Management Entrechment : The Case of ManagerSpecific Investment, Journal of Financial Economics, Vol. 25.

Shleifer, A. and Robert W. Vishny, 1997, A Survey of Corporate Governance, The Journal of Finance, Vol. 52, No. 2.

Taridi (1999),"Corporate Governance, Ownership Concentration and Its Impact on Firms Performance and Firms Debt in Listed Companies in Indonesia", The Indonesian Quarterly, vol. XXVI, pp. 339-355.

Zhuang, Juzhong, David Edwards, David Webb, Ma. Virginita A. Capulong (2000)," Corporate Governance and Finance in East Asia - A Study of Indonesia, Republic of Korea, Malaysia, Philippines, and Thailand", Asian Development Bank, Manila. 